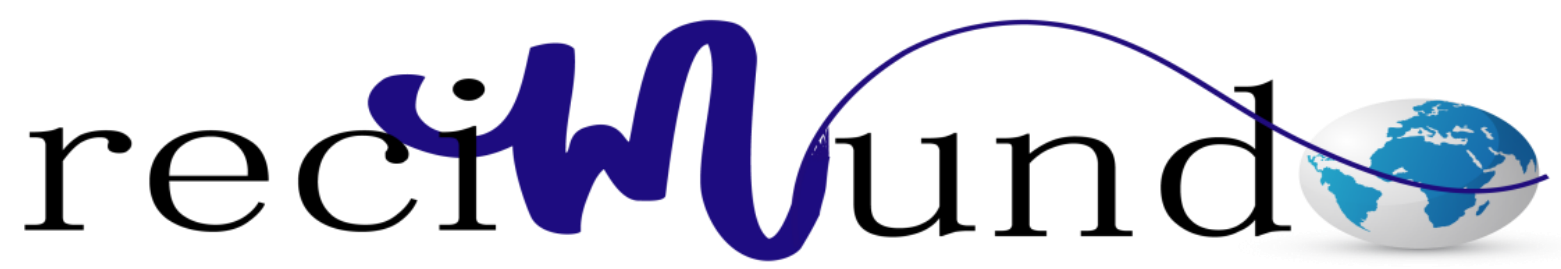

Revista Científica Mundo de la Investigación y el Conocimiento

Nefi Manuel Galán Cherrez a ; Jeimi Patricia Maya Montalvan ${ }^{\text {b }}$; Oswaldo Edison Garcia Brito ${ }^{c}$; Steffany Katherine Montece Ochoa ${ }^{d}$

Impact of the use of selected Youtube videos to enhance the speaking performance on a2 efl learners of an ecuadorian public high school

Impacto del uso de videos de Youtube seleccionados para mejorar el rendimiento de la oratoria en alumnos de a 2 efl de una escuela secundaria pública ecuatoriana

Revista Científica Mundo de la Investigación y el Conocimiento. Vol. 2 núm.3, julio, ISSN: 2588-073X, 2018, pp. 199-226

DOI: 10.26820/recimundo/2.(3).julio.2018.199-226

Editorial Saberes del Conocimiento

Recibido: 05/04/2018

Aceptado: 15/05/2018

Publicado: 30/07/2018

Correspondencia: nefi.galanch@ug.edu.ec

a. Magister en Enseñanza de Inglés como Lengua Extranjera; Licenciado en Ciencias de la Educación mención Ingles; Universidad de Guayaquil; nefi.galanch@ug.edu.ec

b. Magister en Enseñanza de Inglés como Lengua Extranjera; Licenciada en Ciencias de la Educación Mención Lengua Inglesa y Lingüística; Universidad de Guayaquil; jeimi.mayam@ug.edu.ec

c. Magister en Enseñanza de Inglés como Lengua Extranjera; Diploma Superior en Diseño Curricular por Competencias; Magister en Diseño Curricular; Ingeniero Agrónomo; Universidad de Guayaquil; oswaldo.garciab@ug.edu.ec 


\section{Impact of the use of selected Youtube videos to enhance the speaking performance on a2 efl learners of an ecuadorian public high school}

Vol. 2, núm. 3., (2018)

Nefi Manuel Galán Cherrez; Jeimi Patricia Maya Montalvan; Oswaldo Edison Garcia Brito; Steffany Katherine Montece Ochoa

\section{ABSTRACT}

The present research study aims to evaluate the impact of the use of selected YouTube videos for enhancing learners' speaking performance in English foreign learners (EFL) of A2 level at an Ecuadorian public high school. Normally, by the time Ecuadorian public high school students end their senior year, they are not yet able to effectively communicate in English. Consequently, the requirements established in the curriculum by the Ecuadorian Ministry of Education regarding English teaching as a foreign language are not being successfully accomplished. It is believed that scaffolding speaking lessons with the aid of audio visual materials may bring about effective results regarding communicative performance. Subsequently, quantitative and qualitative instruments will gather data for its coding and analysis. In addition, results suggest that selected YouTube videos bring positive results if classes are elaborated with before, during and after video communicative tasks. Last but not least, implications indicate that classroom environment may affect students' performance.

Key words: Selected YouTube videos, speaking performance, Ecuadorian high school students, EFL learners. 


\section{Impact of the use of selected Youtube videos to enhance the speaking performance on 2 efl learners of an ecuadorian public high school}

Vol. 2, núm. 3., (2018)

Nefi Manuel Galán Cherrez; Jeimi Patricia Maya Montalvan; Oswaldo Edison Garcia Brito;

Steffany Katherine Montece Ochoa

\section{RESUMEN}

El presente estudio de investigación tiene como objetivo evaluar el impacto del uso de videos seleccionados de YouTube para mejorar el rendimiento de la conversación de los estudiantes en inglés como idioma extranjero (EFL) de nivel A2 en una escuela secundaria pública ecuatoriana. Normalmente, cuando los estudiantes ecuatorianos de educación secundaria finalizan su último año, todavía no pueden comunicarse de manera efectiva en inglés. En consecuencia, los requisitos establecidos en el plan de estudios por el Ministerio de Educación ecuatoriano con respecto a la enseñanza del inglés como lengua extranjera no se están logrando con éxito. Se cree que las lecciones de andamiaje con la ayuda de materiales audiovisuales pueden producir resultados efectivos con respecto al rendimiento comunicativo. Posteriormente, los instrumentos cuantitativos y cualitativos recopilarán datos para su codificación y análisis. Además, los resultados sugieren que los videos de YouTube seleccionados arrojan resultados positivos si las clases se elaboran con antes, durante y después de las tareas comunicativas de video. Por último, pero no menos importante, las implicaciones indican que el ambiente del aula puede afectar el rendimiento de los estudiantes.

Palabras claves: Videos de YouTube seleccionados, presentaciones orales, estudiantes de secundaria ecuatorianos, estudiantes de EFL. 


\section{Impact of the use of selected Youtube videos to enhance the speaking performance on a2 efl learners of an ecuadorian public high school}

Vol. 2, núm. 3., (2018)

Nefi Manuel Galán Cherrez; Jeimi Patricia Maya Montalvan; Oswaldo Edison Garcia Brito; Steffany Katherine Montece Ochoa

\section{Introduction.}

The present study addresses an educational issue regarding English teaching in an Ecuadorian public high school for adult learners. The researchers believe certain public high schools, particularly the night ones, do not have enough resources. In addition, their teachers do not have sufficient training to help their students to achieve a B1 (intermediate) English level as required by the official public high school curriculum (Ministero de Educación del Ecuador, 2016).

The Ecuadorian Educational law requires that students acquire a B1level according to the Common European Framework Reference of Languages (CEFR) before they graduate. In our researchers' experience one of the problems that adult students have when trying to achieve this goal is the use of conversational English. To facilitate the use of conversational English in this group, we study the impact of selected YouTube videos on speaking performance in EFL A2 learners of an Ecuadorian public high school.

As English teachers we have worked a little over a decade. Due to our teaching experience we have noticed that most public night high schools in Ecuador lack of English teaching resources, effective teaching training, and professional development opportunities. As a result of these issues, students are not able to obtain an English B1 CEFR level at the end of their senior year in high school as expected by the Ecuadorian national curriculum specifications (Ministerio de Educación, 2012). 


\section{Impact of the use of selected Youtube videos to enhance the speaking performance on a 2 efl learners of an ecuadorian public high school}

Vol. 2, núm. 3., (2018)

Nefi Manuel Galán Cherrez; Jeimi Patricia Maya Montalvan; Oswaldo Edison Garcia Brito; Steffany Katherine Montece Ochoa

The Ecuadorian Learning Teacher Standards are based on the document developed by the Teachers of English to Speaker of other languages (TESOL) along with the K-12 ESL teacher standards (2009) which is used in countries such as Paraguay, Albania, and the United States (Ministerio de Educación, 2017).

Since Ecuador is a multicultural country, educators have to adapt their teaching depending on the origin, culture, and social background of the learners. In addition, teachers ought to use technological and other classroom resources to enable learners develop language skills for communication. According to the English learning standards, Ecuadorian high school students will be able to attain a B1 CEFR level at the end of $3^{\text {rd }}$ senior high school year. The English Language Learning standards take into account communicative language components and skills in their program: listening, speaking, writing, and reading. The B1 curriculum projection for EFL Ecuadorian learners has been implemented since the year 2012; nevertheless, this educational law will not be enforced until the school year 2016-2017 in the highlands and Amazon region, and the school year 2017-2018 in the Costal and Galapagos region (Ministerio de Educación, 2012).

In the past lots of students at public schools had been struggling in their learning not just in the English field, but in other fields too. Due to educational drawbacks, the Ecuadorian government of the $21^{\text {st }}$ century implemented an Educational reform to help students attain desired learning goals. One of the goals in the English field is to help Ecuadorian students to have access to higher education at prestigious universities around the globe. Nevertheless, most of those universities require a B2 English level in order for students to meet the demands of the 


\section{Impact of the use of selected Youtube videos to enhance the speaking performance on a2 efl learners of an ecuadorian public high school}

Vol. 2, núm. 3., (2018)

Nefi Manuel Galán Cherrez; Jeimi Patricia Maya Montalvan; Oswaldo Edison Garcia Brito; Steffany Katherine Montece Ochoa

language of instruction. Ecuadorian learners at public schools have not yet met those demands (British Council, 2015).

In 2012, for the first time in Ecuadorian history, English public school teachers were evaluated on their level of English proficiency. The results were astonishing, only $0.93 \%$ of teachers (38 teachers) scored a B2 level. These results clearly tell us that if most teachers could not obtain a B2 level, neither would their students attain a B2 nor a B1 level. The Ecuadorian government has signed an agreement with ETS to help their teachers improve their English proficiency level. In addition, teachers had been sent abroad to improve both their English proficiency and their teaching methods and approaches. Since then, there has been a gradual change; however, there are still some public schools in which little effort is made to improve English teaching (Ureña, 2014).

In our study, we intend to incorporate 6 selected YouTube videos with the purpose of enhancing the students' English speaking performance. In addition, we wish to help senior high school adult students to use English for communicative purposes. One of the issues in our study is participants' lack of time to be present in all classes. Some of these students are not able to comply with the demands of their teachers because they either have to work or stay home to look after their loved ones. Some of these adults are parents and others are the breadwinners. According to their English teacher, this issue has long been neglected by the authorities of the school. In short, we will apply our treatment regardless of the circumstances of our participants' personal lives. 


\section{Impact of the use of selected Youtube videos to enhance the speaking performance on a 2 efl learners of an ecuadorian public high school}

Vol. 2, núm. 3., (2018)

Nefi Manuel Galán Cherrez; Jeimi Patricia Maya Montalvan; Oswaldo Edison Garcia Brito; Steffany Katherine Montece Ochoa

Adult learners are faced with many struggles to learn a foreign language. One struggle is neuroplasticity. Adult learners do not grasp information as quickly as children do; nevertheless, adults have developed other skills such as metacognitive awareness; they can relate new information to prior learning experiences. Adults have a busy agenda. For instance, they have family issues to take care, social meetings to attend, etc. These matters can affect their performance as they occupy their attention. It is important for adult teachers to come prepared to class to minimize time gaps so that students do not think on their problems. Teachers must create engaging activities in which no one is left out. Last but not least, adults are accustomed to higher expectations; when adult students score low, it is essential to provide feedback to bridge gaps. If feedback is not provided, adults may become reluctant learners (Mac Donnchaidh, 2015) .

The aim of our study is to evaluate the impact of selected YouTube videos for enhancing A2 EFL learners' English speaking performance at an Ecuadorian public night high school.

\section{Methodology.}

In our study, we as researchers have decided to employ action research. Action research is a process by which research practitioners and participants work together with the purpose of solving an issue. In action research, research practitioners put theory into practice. In addition, investigators work towards practical outcomes through the creations of new forms of understanding with the purpose of aiding a particular community. Equally important, action research is considered significant since it does not only lead to practical knowledge but also to the creation of new knowledge (Reason \& Bradbury, 2007). 


\section{Impact of the use of selected Youtube videos to enhance the speaking performance on a2 efl learners of an ecuadorian public high school}

Vol. 2, núm. 3., (2018)

Nefi Manuel Galán Cherrez; Jeimi Patricia Maya Montalvan; Oswaldo Edison Garcia Brito; Steffany Katherine Montece Ochoa

It is imperative to mention that in our study we are working with adults. To understand adult learning (andragogy), it is fundamental to have a notion of children's learning (pedagogy). In pedagogy, the teacher is accountable and responsible for the learning decisions such as what is to be learned, how new concepts will be learned, when new concepts will be learned and so forth. On the other hand, andragogy copes with mutuality and reciprocity between teacher and students. Both teacher and students contribute with learning experience, feedback and assessment (Caruth, 2013).

The videos selected for our intervention are based on the level of the participants. Below we give you a full description of each vision:

1. The name of the video is "What is your name?" "Where are you from?" The purpose of the video lesson is to acquaint learners with the vocabulary related to countries and places (Marzio, 2011).

2. The author of this video is Mark Kulek. This author uploads ESL English on YouTube to help people learn English. The purpose of the video is to enable learners elaborate yes/no questions with the auxiliaries do, does, and did. We did not show the entire video because our purpose was to enable students to formulate present tense questions with the auxiliaries do and does (Kulek, Daily Routines, 2016).

3. The topic of the video is information questions in the present tense with the auxiliaries do and does. The video also focused on vocabulary about occupations and verbs related to sports (Kulek, What do they do?, 2015). 


\section{Impact of the use of selected Youtube videos to enhance the speaking performance on 2 efl learners of an ecuadorian public high school}

Vol. 2, núm. 3., (2018)

Nefi Manuel Galán Cherrez; Jeimi Patricia Maya Montalvan; Oswaldo Edison Garcia Brito; Steffany Katherine Montece Ochoa

4. The ESL Company Side by Side made this video. The purpose of this video is to help students use the auxiliary "Can" when we talk about occupations and abilities (Side by side, 2012).

5. The source of this video englishwithsoundlight.com. The purpose of this video is to introduce simple present tense through context. The video featured routines and habits of various people. Written questions appeared on the video to facilitate learners' comprehension (Shea, 2010)

6. The last video is called the Family Tree. The purpose of this video is to enable students to identify common family names in a family tree. In the family tree, each family member spoke. The video also presented present tense verb "be" sentences about family members' vocabulary (Real English Conversation, 2015).

\section{Methods of data collection}

For our research, we will administer quantitative and qualitative data collection instruments. The pre-test and the post-test will measure data quantitatively; whereas, the Likertscale questionnaire and the observation format will measure data qualitatively. The data collection instruments for our investigation will be used in the following way:

Questionnaire: An anonymous questionnaire with a close-ended Likert-Scale will be provided to all participants of the experimental group (30 students) every session (35 minutes each session) (See appendix A). The categories on the Likert-scale are very, somewhat, a little, and not at all. These categories will facilitate participants to choose how interesting, useful, helpful, pertinent, appropriate and comprehensible the selected YouTube videos are. The Likert 


\section{Impact of the use of selected Youtube videos to enhance the speaking performance on a2 efl learners of an ecuadorian public high school}

Vol. 2, núm. 3., (2018)

Nefi Manuel Galán Cherrez; Jeimi Patricia Maya Montalvan; Oswaldo Edison Garcia Brito; Steffany Katherine Montece Ochoa

scale questionnaire is in Spanish (L1) to avoid confusion on the part of the learners. Wang, Hong \& Hsu (2006) explained that close-ended rating scale questionnaires permit to capture intended information by wording each question; these keywords appropriately represent the subjects of questions. As cited by (Gabrys, Howlett \& Jain, 2006).

Observation Formats: In the observation formats, there are six criteria and the number of students who may or may not fall into these criteria. The criteria are students repeat what they hear, students ask their teacher questions, students answer questions in Spanish (L1), students work with their peers (in dialogues, role-plays, and drills), students provide short responses in L2, students provide long responses in L2. (See appendix B). This observation helps researchers record every instance of the target behavior which is English oral production. Structured observation is a systematical data gathering technique which allows researchers to record behavior through categorization (variables and indicators) (Bryman, 2008)

Pre-Test and Post-Test: The tests will be administered by the researchers of the study based on the guidelines of the KET (Key English Test) (See Appendix I) Cambridge test and also the unit content established by the school curriculum. This test will be the main instrument to measure the students speaking performance (pre-test and post-test). The pre-test will be given to 15 students from another course to ensure test reliability. Pre-test and post- test is one of the most effective research designs because it provides scientific control over threats to internal validity. Also, it facilitates the analysis of variables through the Paired T Test statistical method (Huck \& McLean, 1975). 


\section{Impact of the use of selected Youtube videos to enhance the speaking performance on a 2 efl learners of an ecuadorian public high school}

Vol. 2, núm. 3., (2018)

Nefi Manuel Galán Cherrez; Jeimi Patricia Maya Montalvan; Oswaldo Edison Garcia Brito; Steffany Katherine Montece Ochoa

Once all the data is gathered, it is coded to find patterns of behaviors. Coding is defined as the interpretation of information and question responses through data categorization for the whole purpose of its analysis (Kerlinger, 1970).

\section{Selection and handling of data}

Six selected YouTube Speaking Lessons will be given to the class. Also, six speaking tasks related to the selected YouTube videos are given to the class. Each speaking lesson will be given twice a week for three weeks. Each speaking lesson lasts 35 minutes. During the six lessons students will work on several tasks such as predicting, genre guessing, giving opinions, vocabulary building, and asking and answering questions to the teacher and to each other. Some of the lessons will be video recorded to facilitate understanding of the observation format.

\section{Participants}

The participants of our study are adult high school students from a public night high school in the coastal region of Ecuador. These students attend classes during the evening.

\section{Selection of the Sampling}

In our study, we have decided to employ convenience sampling because it was better for us to select an intact group that will be more appropriate for our intervention. The course we selected was a night course in a public high school in Guayaquil. We selected that specific course because the students started classes at night time, and since neither of us had time during the day, thus the course became the right one for us. Also, the course had a significant population 


\section{Impact of the use of selected Youtube videos to enhance the speaking performance on a2 efl learners of an ecuadorian public high school}

Vol. 2, núm. 3., (2018)

Nefi Manuel Galán Cherrez; Jeimi Patricia Maya Montalvan; Oswaldo Edison Garcia Brito; Steffany Katherine Montece Ochoa

size of 42 of which 30 students decided to become our sample. Last but not least, this high school does not have technological equipment; and this allowed us to implement a class that would be new to them, in this case, speaking lessons with the aid of selected YouTube videos. Convenience Sampling falls into the category of non-probability sampling because it allows researchers to select a group that meets certain criteria such as geographical distance, time availability, willingness to volunteer, and so forth. (Dörnyei, 2007).

\section{Background of the participants}

Most of these participants come from marginal areas of Guayaquil. Also, the great majority of these students have to work to support their families; this is the reason why they study in the evening. Among these students, we have mothers, fathers, and young adults. Since these students come from low social classes, it is difficult for them to afford top of the range English courses at private entities.

\section{Results.}

We present the results from the questionnaires of students' attitude about the six videos we presented. We also describe the results of the study by using graphs and tables. The figures will show the results of the questionnaire in percentages. In addition, a table with the results in numbers accompanied the graph. There are seven tables describing the results numerically and forty-two bar graphs describing the results graphically that identify the results obtained in the questionnaire that was filled out by the students at the end of each class. Every graph represents each question. 


\section{Impact of the use of selected Youtube videos to enhance the speaking performance on a 2 efl learners of an ecuadorian public high school}

Vol. 2, núm. 3., (2018)

Nefi Manuel Galán Cherrez; Jeimi Patricia Maya Montalvan; Oswaldo Edison Garcia Brito; Steffany Katherine Montece Ochoa

We also added a numerical and graphical figure of the results of the Pre-test and Post-test. The table 8 shows the number of the students (30) with their corresponding score of the Pre-test and Post-test. In addition, this section provides the results of the scores in the tests through a Box Plot, the Pre-test was administered before the six classes and the Post-test, which is the same evaluation, was administered at the end.

Furthermore, we display 6 line graphs that provide the results in numbers of the observation formats, which were filled out by us with the support of the recorded classes.

\section{Results from the questionnaires}

The participants received six different classes with the help of six different selected YouTube videos chosen by the researchers.

Researchers asked them to complete a questionnaire at the end of each class. This questionnaire assembled different questions related to some aspects of the video. These questions were written in Spanish to avoid misunderstandings.

1. Was the video interesting?

2. Was the video useful?

3. Did the video have daily life phrases?

4. Was the video related to the topic of the class?

5. Did the video help me to understand the class?

6. Was the time of the video appropriate?

7. Was the vocabulary comprehensible? 


\section{Impact of the use of selected Youtube videos to enhance the speaking performance on 2 efl learners of an ecuadorian public high school}

Vol. 2, núm. 3., (2018)

Nefi Manuel Galán Cherrez; Jeimi Patricia Maya Montalvan; Oswaldo Edison Garcia Brito; Steffany Katherine Montece Ochoa

Class \# 1.- What is your name? Where are you from?

This video shows an interviewer walking on the street and asking a few questions to the pedestrians. The questions were: What's your name? Can you spell it? And Where are you from? The students' opinions were as follows.

For the lesson plan see Appendix C.

\section{Table $N^{\circ} 1 .-$ Questionnaire summary - Class 1}

\begin{tabular}{|l|l|c|c|c|c|c|}
\hline \multicolumn{1}{|l|}{ Ítem } & \multicolumn{1}{|c|}{ STA Tery } & Somewhat & $\begin{array}{c}\text { Not at } \\
\text { little }\end{array}$ & $\begin{array}{c}\text { Total } \\
\text { all }\end{array}$ & \\
\hline 1 & Was the video interesting? & 22 & 6 & 1 & 1 & 30 \\
\hline 2 & Was the video useful? & 17 & 9 & 3 & 1 & 30 \\
\hline 3 & Did the video have daily life phrases? & 20 & 7 & 2 & 1 & 30 \\
\hline 4 & Was the video related to the topic? & 22 & 7 & 0 & 1 & 30 \\
\hline 5 & $\begin{array}{l}\text { Did the video help me to understand } \\
\text { the class? }\end{array}$ & 18 & 10 & 2 & 0 & 30 \\
\hline 6 & $\begin{array}{l}\text { Was the time of the video } \\
\text { appropriate? }\end{array}$ & 18 & 10 & 2 & 0 & 30 \\
\hline 7 & Was the vocabulary comprehensible? & 20 & 8 & 2 & 0 & 30 \\
\hline
\end{tabular}

This table shows the questionnaires' results of the first class in numbers. In this first class all the participants showed up. The following charts show the results of each question in percentages. 


\section{Impact of the use of selected Youtube videos to enhance the speaking performance on 2 efl learners of an ecuadorian public high school}

Vol. 2, núm. 3., (2018)

Nefi Manuel Galán Cherrez; Jeimi Patricia Maya Montalvan; Oswaldo Edison Garcia Brito;

Steffany Katherine Montece Ochoa

Was the video interesting?

According to what the students answered in the surveys. The results showed that $73.3 \%$ (number of students) think that the video was very interesting. The $20 \%$ expressed that the video was somewhat interesting. The $3.3 \%$ thought that the video was a little interesting and the rest $3.3 \%$ of the participants said that the video was not at all interesting.

Was the video useful?

In the second question, $56.7 \%$ think that the video was very useful. The $30 \%$ expressed that the video was somewhat useful. The $10 \%$ thought it was not at all useful.

Did the video have daily life phrases?

In the third question, $66.7 \%$ think that the video had many daily life phrases. The $23.3 \%$ expressed that the video had some daily life phrases. The $6.7 \%$ think that the video had a few daily life phrases the $3.3 \%$ of the participants say that the video was not at all useful.

Was the video related to the topic?

In the fourth question, $73.3 \%$ think that the video was much related to the topic. The $23.3 \%$ expressed that the video had some relation to the topic. The $0.0 \%$ thought that the video had a little relationship with the topic. The $3.3 \%$ of the participants say that the video was not at all related to the topic.

Did the video help me to understand the class? 


\section{Impact of the use of selected Youtube videos to enhance the speaking performance on a2 efl learners of an ecuadorian public high school}

Vol. 2, núm. 3., (2018)

Nefi Manuel Galán Cherrez; Jeimi Patricia Maya Montalvan; Oswaldo Edison Garcia Brito; Steffany Katherine Montece Ochoa

In the fifth question, $60 \%$ of the students answered that the video helped them a lot to understand the class. $33.3 \%$ said that the video helped them somewhat to understand the class, and the $6.7 \%$ said that the video helped them a little to understand the class.

Was the time of the video appropriate?

In the sixth question about the time of the video, the $60 \%$ of the participants said that the time of the video was very appropriate, the $33.3 \%$ said that the time was somewhat appropriate. Moreover, the $6.7 \%$ expressed that the time was not very appropriate.

Was the vocabulary comprehensible?

In the seventh question, the $66.7 \%$ of the participants said that the vocabulary was very comprehensible. The $26.7 \%$ expressed that the vocabulary was somewhat comprehensible. On the other hand, the $6.7 \%$ said that the vocabulary was a little comprehensible.

Table $N^{\circ} 1 .-$ Questionnaire summary - Class 2

\begin{tabular}{|c|l|c|c|c|c|c|}
\hline Item & \multicolumn{1}{|c|}{ STA TEMIENTS } & Very & Somewhat & Little & Not at all & Total \\
\hline 1 & Was the video interesting? & 18 & 9 & 2 & 1 & 30 \\
\hline 2 & Was the video useful? & 18 & 8 & 3 & 1 & 30 \\
\hline 3 & $\begin{array}{l}\text { Did the video have daily life } \\
\text { phases? }\end{array}$ & 16 & 9 & 4 & 1 & 30 \\
\hline 4 & Was the video related to the topic? & 19 & 5 & 3 & 3 & 30 \\
\hline 5 & $\begin{array}{l}\text { Did the video help me to understand } \\
\text { the class? }\end{array}$ & 15 & 12 & 2 & 1 & 30 \\
\hline 6 & $\begin{array}{l}\text { Was the time of the video } \\
\text { appropriate? }\end{array}$ & 15 & 9 & 3 & 3 & 30 \\
\hline 7 & $\begin{array}{l}\text { Was the vocabulary } \\
\text { comprehensible? }\end{array}$ & 14 & 12 & 2 & 2 & 30 \\
\hline
\end{tabular}




\section{Impact of the use of selected Youtube videos to enhance the speaking performance on a 2 efl learners of an ecuadorian public high school}

Vol. 2, núm. 3., (2018)

Nefi Manuel Galán Cherrez; Jeimi Patricia Maya Montalvan; Oswaldo Edison Garcia Brito; Steffany Katherine Montece Ochoa

The second video presented shows several occupations; also it shows Yes/No questions or information questions related to occupations. For example, Do you Work? What do you do? I am a mechanic.

Was the video interesting?

According to what the students answered in the questionnaires. The results showed that $60 \%$ think that the video was very interesting. The $30 \%$ expressed that the video was somewhat interesting. The $6.7 \%$ thought that the video was a little interesting and the rest $3.3 \%$ of the participants say that the video was not at all interesting.

Was the video useful?

In the second question, $60 \%$ think that the video was very useful. The $26.7 \%$ expressed that the video was somewhat useful. The $10 \%$ thought that the video was a little useful and the $3.3 \%$ of the participants say that the video was not at all useful.

Did the video have daily life phases?

In the third question, $53.3 \%$ think that the video had many daily life phrases. The $30 \%$ expressed that the video had some daily life phrases. The $13.3 \%$ think that the video had a few daily life phrases- Finally, the $3.3 \%$ of the participants say that the video was not at all useful.

Was the video related to the topic? 


\section{Impact of the use of selected Youtube videos to enhance the speaking performance on a2 efl learners of an ecuadorian public high school}

Vol. 2, núm. 3., (2018)

Nefi Manuel Galán Cherrez; Jeimi Patricia Maya Montalvan; Oswaldo Edison Garcia Brito; Steffany Katherine Montece Ochoa

In the fourth question, $63.3 \%$ think that the video was much related to the topic. The $16.7 \%$ expressed that the video had some relation to the topic. The $10 \%$ think that the video had a little relationship with the topic. The $10 \%$ of the participants say that the video was not at all related to the topic.

Did the video help me to understand the class?

In the fifth question, $50 \%$ of the students answered that the video helped them a lot to understand the class. $40 \%$ said that the video helped them somewhat to understand the class, and the $6.7 \%$ said that the video helped them a little to understand the class. Finally, the 3.3 of the participants thought that the video did not help to understand the class

Was the time of the video appropriate?

In the sixth question about the time of the video, the $50 \%$ of the participants said that the time of the video was very appropriate, the $30 \%$ said that the time was somewhat appropriate. Moreover, the $10 \%$ expressed that the time was not very appropriate. Finally, the $10 \%$ thought that the time of the video was not adequate.

Was the vocabulary comprehensible?

In the seventh question, the $46.7 \%$ of the participants said that the vocabulary was very understandable. The $40 \%$ expressed that the vocabulary was somewhat comprehensible. On the other hand, the $6.7 \%$ said that the vocabulary was a little comprehensible. 


\section{Impact of the use of selected Youtube videos to enhance the speaking performance on a 2 efl learners of an ecuadorian public high school}

Vol. 2, núm. 3., (2018)

Nefi Manuel Galán Cherrez; Jeimi Patricia Maya Montalvan; Oswaldo Edison Garcia Brito;

Steffany Katherine Montece Ochoa

Table $N^{\circ}$ 3.- Questionnaire Summary-class 3

\begin{tabular}{|c|c|c|c|c|c|c|}
\hline Ítem & STATEMENTS & Very & Somewhat & \begin{tabular}{|l} 
A \\
little
\end{tabular} & $\begin{array}{c}\text { Not at } \\
\text { all }\end{array}$ & Total \\
\hline 1 & Was the video interesting? & 21 & 3 & 3 & 0 & 27 \\
\hline 2 & Was the video useful? & 19 & 4 & 3 & 1 & 27 \\
\hline 3 & Did the video have daily life phrases? & 15 & 8 & 4 & 0 & 27 \\
\hline 4 & Was the video related to the topic? & 15 & 10 & 2 & 0 & 27 \\
\hline 5 & $\begin{array}{l}\text { Did the video help me understand the } \\
\text { class? }\end{array}$ & 19 & 5 & 3 & 0 & 27 \\
\hline 6 & $\begin{array}{l}\text { Was the time of the video } \\
\text { appropriate? }\end{array}$ & 20 & 7 & 0 & 0 & 27 \\
\hline 7 & Was the vocabulary comprehensible? & 21 & 3 & 1 & 2 & 27 \\
\hline
\end{tabular}

Was the video interesting?

According to what the students answered in the questionnaire, the results showed that $77.8 \%$ think that the video was very interesting. The $11.1 \%$ expressed that the video was somewhat interesting. The $11.1 \%$ thought that the video was a little interesting.

Was the video useful?

In the second question, $70.4 \%$ thought that the video was very useful. The $14.8 \%$ expressed that the video is somewhat useful. The $11.1 \%$ thought that the video was a little useful and the $3.7 \%$ of the participants say that the video was not at all useful.

Did the video have daily life phrases?

In the third question, $55.6 \%$ think that the video had many daily life phrases. The $29.6 \%$ expressed that the video had some daily life phrases. The $14.8 \%$ thought that the video had a few daily life phrases. 


\section{Impact of the use of selected Youtube videos to enhance the speaking performance on a2 efl learners of an ecuadorian public high school}

Vol. 2, núm. 3., (2018)

Nefi Manuel Galán Cherrez; Jeimi Patricia Maya Montalvan; Oswaldo Edison Garcia Brito; Steffany Katherine Montece Ochoa

Was the video related to the topic?

In the fourth question, $55.6 \%$ think that the video is much related to the topic. The $37 \%$ expressed that the video had some relation to the topic. The $7.4 \%$ thought that the video had a little relationship with the topic.

Did the video help me understand the class?

In the fifth question, $70.4 \%$ of the students answered that the video helped them a lot to understand the class. $18.5 \%$ said that the video helped them somewhat to understand the class, and the $11 \%$ said that the video helped them a little to understand the class.

Was the time of the video appropriate?

In the sixth question about the time of the video, the $74.1 \%$ of the participants said that the time of the video was very appropriate and the $25.9 \%$ said that the time was somewhat appropriate.

Was the vocabulary comprehensible?

In the seventh question, the $77.8 \%$ of the participants said that the vocabulary was very comprehensible. The $11.1 \%$ expressed that the vocabulary was somewhat comprehensible. On the other hand, the $3.7 \%$ said that the vocabulary was a little comprehensible. Finally, the $7.4 \%$ of the participants said that the vocabulary was not comprehensible enough. 


\section{Impact of the use of selected Youtube videos to enhance the speaking performance on a 2 efl learners of an ecuadorian public high school}

Vol. 2, núm. 3., (2018)

Nefi Manuel Galán Cherrez; Jeimi Patricia Maya Montalvan; Oswaldo Edison Garcia Brito;

Steffany Katherine Montece Ochoa

\section{Table $N^{\circ}$ 4.- Questionnaire Summary - Class 4}

\begin{tabular}{|c|l|c|c|c|c|c|}
\hline Ítem & \multicolumn{1}{|c|}{ STA TEMIENTS } & Very & Somewhat & $\begin{array}{c}\text { Not } \\
\text { little } \\
\text { at } \\
\text { all }\end{array}$ & $\begin{array}{c}\text { Total } \\
\text { surveyed }\end{array}$ \\
\hline 1 & $\begin{array}{l}\text { Was the video interesting? } \\
\text { Was the video useful? }\end{array}$ & 18 & 4 & 0 & 0 & 30 \\
\hline 3 & $\begin{array}{l}\text { Did the video have daily life } \\
\text { phrases? }\end{array}$ & 19 & 7 & 4 & 0 & 30 \\
\hline 4 & $\begin{array}{l}\text { Was the video related to the topic? } \\
\text { Did the video help me to understand } \\
\text { the class? }\end{array}$ & 19 & 7 & 4 & 0 & 30 \\
\hline 6 & $\begin{array}{l}\text { Was the time of the video } \\
\text { appropriate? }\end{array}$ & 16 & 13 & 1 & 1 & 30 \\
\hline 7 & $\begin{array}{l}\text { Was the vocabulary } \\
\text { comprehensible? }\end{array}$ & 11 & 3 & 0 & 30 \\
\hline
\end{tabular}

Was the video interesting?

According to what the students answered in the questionnaire. The results showed that $86.7 \%$ think that the video was very interesting. The $13.3 \%$ expressed that the video was somewhat interesting.

Was the video useful?

In the second question, $60 \%$ think that the video is very useful. The $40 \%$ expressed that the video was somewhat useful.

Did the video have daily life phrases?

In the third question, $63.3 \%$ think that the video had many daily life phrases. The $23.3 \%$ expressed that the video had some daily life phrases. The $13.3 \%$ thought that the video had a few daily life phrases. 


\section{Impact of the use of selected Youtube videos to enhance the speaking performance on 22 efl learners of an ecuadorian public high school}

Vol. 2, núm. 3., (2018)

Nefi Manuel Galán Cherrez; Jeimi Patricia Maya Montalvan; Oswaldo Edison Garcia Brito; Steffany Katherine Montece Ochoa

Was the video related to the topic?

In the fourth question, $63.3 \%$ think that the video was much related to the topic. The $23.3 \%$ expressed that the video had some relation to the topic. The $13.3 \%$ thought that the video had a little relationship with the topic. The $0.0 \%$ of the participants say that the video was not related at all to the topic.

Did the video help me to understand the class?

In the fifth question, $53.3 \%$ of the students answered that the video helped them a lot to understand the class. $40 \%$ said that the video helped them somewhat to understand the class. The $3.3 \%$ said that the video helped them a little to understand the class. The rest $3.3 \%$ thinks that the video did not help them to understand the class at all.

Was the time of the video appropriate?

In the sixth question about the time of the video, the $53.3 \%$ of the participants said that the time of the video was very appropriate, the $43.3 \%$ said that the time was somewhat appropriate. Finally, the $3.3 \%$ expressed that the time was a little appropriate.

Was the vocabulary comprehensible?

In the seventh question, the $53.3 \%$ of the participants said that the vocabulary was very comprehensible. The $36.7 \%$ expressed that the vocabulary was somewhat comprehensible. On the other hand, the $10 \%$ said that the vocabulary was a little comprehensible. 


\section{Impact of the use of selected Youtube videos to enhance the speaking performance on a 2 efl learners of an ecuadorian public high school}

Vol. 2, núm. 3., (2018)

Nefi Manuel Galán Cherrez; Jeimi Patricia Maya Montalvan; Oswaldo Edison Garcia Brito;

Steffany Katherine Montece Ochoa

\section{Table $N^{\circ}$ 5.- Questionnaire Summary - Class 5}

\begin{tabular}{|c|l|c|c|c|c|c|}
\hline Ítem & \multicolumn{1}{|c|}{ STA TEMIENTS } & Very & Somewhat & Little & $\begin{array}{c}\text { Not at } \\
\text { all }\end{array}$ & Total \\
\hline 1 & Was the video interesting? & 19 & 6 & 0 & 0 & 25 \\
\hline 2 & Was the video useful? & 16 & 9 & 0 & 0 & 25 \\
\hline 3 & $\begin{array}{l}\text { Did the video have daily life } \\
\text { phrases? }\end{array}$ & 19 & 5 & 0 & 1 & 25 \\
\hline 4 & Was the video related to the topic? & 22 & 3 & 0 & 0 & 25 \\
\hline 5 & $\begin{array}{l}\text { Did the video help me to } \\
\text { understand the class? }\end{array}$ & 14 & 10 & 0 & 1 & 25 \\
\hline 6 & Was the time appropriate? & 15 & 8 & 0 & 3 & 25 \\
\hline 7 & $\begin{array}{l}\text { Was the vocabulary } \\
\text { comprehensible? }\end{array}$ & & & & 2 & 25 \\
\hline
\end{tabular}

Was the video interesting?

According to what the students answered in the questionnaire. The results showed that $76 \%$ think that the video was very interesting. The $24 \%$ expressed that the video was somewhat interesting.

Was the video useful?

In the second question, $64 \%$ think that the video was very useful. The $36 \%$ expressed that the video was somewhat useful.

Did the video have daily life phrases?

In the third question, $76 \%$ think that the video had many daily life phrases. The $20 \%$ expressed that the video had some daily life phrases. Finally, the $4 \%$ of the participants say that the video was not at all useful. 


\section{Impact of the use of selected Youtube videos to enhance the speaking performance on a2 efl learners of an ecuadorian public high school}

Vol. 2, núm. 3., (2018)

Nefi Manuel Galán Cherrez; Jeimi Patricia Maya Montalvan; Oswaldo Edison Garcia Brito; Steffany Katherine Montece Ochoa

Was the video related to the topic?

In the fourth question, $88 \%$ think that the video is much related to the topic. The $12 \%$ expressed that the video had some relation to the topic.

Did the video help me to understand the class?

In the fifth question, $56 \%$ of the students answered that the video helped them a lot to understand the class. $40 \%$ said that the video helped them somewhat to understand the class. Finally, the $4 \%$ of the participants did not help to understand the class at all.

Was the time appropriate?

In the sixth question about the time of the video, the $56 \%$ of the participants said that the time of the video was very appropriate, the $32 \%$ said that the time was somewhat appropriate. Finally, the $10 \%$ thought that the time of the video was not at all adequate.

Was the vocabulary comprehensible?

In the seventh question, the $60 \%$ of the participants said that the vocabulary was very understandable. The $32 \%$ expressed that the vocabulary was somewhat comprehensible. On the other hand, the $8 \%$ said that the vocabulary was not at all comprehensible. 


\section{Impact of the use of selected Youtube videos to enhance the speaking performance on 22 efl learners of an ecuadorian public high school}

Vol. 2, núm. 3., (2018)

Nefi Manuel Galán Cherrez; Jeimi Patricia Maya Montalvan; Oswaldo Edison Garcia Brito;

Steffany Katherine Montece Ochoa

\section{Table $N^{\circ}$ 6.- Questionnaire Summary - Class 6}

\begin{tabular}{|c|c|c|c|c|c|c|}
\hline Ítem & STATEMENTS & Very & Somewhat & $\begin{array}{c}\text { A } \\
\text { little }\end{array}$ & $\begin{array}{l}\text { Not at } \\
\text { all }\end{array}$ & Total \\
\hline 1 & Was the video interesting? & 23 & 3 & 0 & 0 & 26 \\
\hline 2 & Was the video useful? & 18 & 8 & 0 & 0 & 26 \\
\hline 3 & $\begin{array}{l}\text { Did the video have daily life } \\
\text { phrases? }\end{array}$ & 18 & 6 & 2 & 0 & 26 \\
\hline 4 & $\begin{array}{l}\text { Was the video related to the topic of } \\
\text { the class? }\end{array}$ & 17 & 7 & 2 & 0 & 26 \\
\hline 5 & $\begin{array}{l}\text { Did the video help me to understand } \\
\text { the class? }\end{array}$ & 17 & 7 & 2 & 0 & 26 \\
\hline 6 & $\begin{array}{l}\text { Was the time of the video } \\
\text { appropriate? }\end{array}$ & 18 & 5 & 2 & 1 & 26 \\
\hline 7 & Was the vocabulary comprehensible? & 17 & 7 & 2 & 0 & 26 \\
\hline
\end{tabular}

Was the video interesting?

The first question of the sixth class, the results showed that $88.5 \%$ thought that the video was very interesting. The $11.5 \%$ expressed that the video was somewhat interesting.

Was the video useful?

In the second question, $69.2 \%$ think that the video was very useful. The $30.8 \%$ expressed that the video was somewhat useful.

Did the video have daily life phrases?

In the third question, $69.2 \%$ think that the video had many daily life phrases. The $23.1 \%$ expressed that the video had some daily life phrases. Finally, the $7.7 \%$ thought that the video had a few daily life phrases.

Was the video related to the topic of the class? 


\section{Impact of the use of selected Youtube videos to enhance the speaking performance on a2 efl learners of an ecuadorian public high school}

Vol. 2, núm. 3., (2018)

Nefi Manuel Galán Cherrez; Jeimi Patricia Maya Montalvan; Oswaldo Edison Garcia Brito; Steffany Katherine Montece Ochoa

In the fourth question, $65.4 \%$ think that the video was much related to the topic. The $26.9 \%$ expressed that the video had some relation to the topic. Finally, the $7.7 \%$ thought that the video had a little relationship with the topic.

Did the video help me to understand the class?

In the fifth question, $65.4 \%$ of the students answered that the video helped them a lot to understand the class. $26.4 \%$ said that the video helped them somewhat to understand the class, and the $7.7 \%$ said that the video helped them a little to understand the class.

Was the time of the video appropriate?

In the sixth question about the time of the video, the $69.2 \%$ of the participants said that the time of the video was very appropriate, the $19.2 \%$ said that the time was somewhat appropriate. Moreover, the $7.7 \%$ expressed that the time was not very appropriate. Finally, the $3.8 \%$ thought that the time of the video was not adequate.

Was the vocabulary comprehensible?

In the seventh question, the $65.4 \%$ of the participants said that the vocabulary was very comprehensible. The $26.9 \%$ expressed that the vocabulary was somewhat comprehensible. On the other hand, the $7.7 \%$ said that the vocabulary was a little comprehensible. 


\section{Impact of the use of selected Youtube videos to enhance the speaking performance on a2 efl learners of an ecuadorian public high school}

Vol. 2, núm. 3., (2018)

Nefi Manuel Galán Cherrez; Jeimi Patricia Maya Montalvan; Oswaldo Edison Garcia Brito;

Steffany Katherine Montece Ochoa

\section{Conclusion.}

In conclusion, selected YouTube videos does help students enhance their English speaking skills if appropriate scaffolding tasks are delivered. Most students' attention was drawn as the videos were shown. Students utilized some of the words from the videos as they worked on speaking tasks. Results of the post-test clearly explained that the intervention was significant for the student. Moreover, the areas of speaking that students improved were pronunciation, fluency and interactive communication. Last but not least, students' attitudes towards selected YouTube videos were overall positive.

\section{Bibliographic.}

Caruth, G. (2013, April 1). Toward an Understanding of Andragogy's Role in the Online Curriculum of the US Higher Education System. International Women Online Journal of Distance Education, pp. 35-44.

Dörnyei, Z. (2007). Research methods in applied linguistics. New York: Oxford University Press.

Kulek, M. (2015, April 30). What do they do? Gifu, Gifu Prefecture, Japan. Retrieved from https://www.youtube.com/watch?v=q1aXK118QY0\&t=113s

Kulek, M. (2016, March 9). Daily Routines. Gifu, Gifu Prefecture, Japan. Retrieved from https://www.youtube.com/watch?v=lbtglBjKogE\&t=36s

Marzio, M. (2011, January 5). Where are you from? Istres, Provence-Alpes-Côte d'Azur, France. Retrieved from https://www.youtube.com/watch?v=MkXcNZckW28\&t=5s

Ministerio de Educación. (2017, Febrero 7). educacion.gob.ec. Retrieved June 23, 2017, from https://educacion.gob.ec/wp-content/uploads/downloads/2017/02/ESTANDARES-DEINGLES.pdf

Ministero de Educación del Ecuador. (2016, 12 15). educacion.gob.ec. Retrieved May 26, 2017, from https://educacion.gob.ec/wp-content/uploads/downloads/2016/08/EFL-forSubnivel-BGU-final-ok.pdf 


\section{Impact of the use of selected Youtube videos to enhance the speaking performance on a2 efl learners of an ecuadorian public high school}

Vol. 2, núm. 3., (2018)

Nefi Manuel Galán Cherrez; Jeimi Patricia Maya Montalvan; Oswaldo Edison Garcia Brito;

Steffany Katherine Montece Ochoa

Real English Conversation. (2015, April 05). Lesson Family tree This is my familyBasic, Basic Vocabulary. New York, New York, USA. Retrieved from https://www.youtube.com/watch?v=TC6XYeDjyvY

Reason \& Bradbury, P. (2007, February 15). Handbook of action research. Inquiry \& participation in search of a world worthy of human aspiration. Thousand Oaks, California, United States: Sage Publications.

Shea, M. (2010, April 12). Simple Present Tense - Part 1. Quebec, Quebec, Canada. Retrieved from https://www.youtube.com/watch?v=7JeWkZ5irA8\&t=162s

Side by side. (2012, November 20). Expressing ability and occupations. Seattle, Wahington, USA. Retrieved from https://www.youtube.com/watch?v=RPDHqfX4PZQ\&t=125s 